\title{
HASIL DAN MOTIVASI BELAJAR SISWA MATA PELAJARAN IPS MELALUI METODE KOOPERATIF TIPE MODELLING THE WAY
}

\author{
Jira \\ Guru SDN 30 Parepare \\ Email: jira@gmail.com
}

\begin{abstract}
This research was conducted in two cycles, namely cycle I which was held 2 times and cycle II which was also held as much as 2 meetings. This research was conducted for 3 months and supplemented by summarizing all existing research results. The result is an increase in student learning in Class V SDN 30 Parepare through the cooperative learning model Modeling The Way is (i) in the first cycle, including the medium category with an average value of 66.25 while in the second cycle progressing with a very high category with an average value - average 78,13, (ii) there was an increase in the learning outcomes of Class $V$ students of SDN 30 Parepare through the Modeling the Way cooperative learning model, both qualitatively and quantitatively. So this model is considered quite effective in teaching, especially in the field of social studies at elementary school level, because it can improve student learning outcomes, both in doing their assignments at school and trying to provide opportunities for students to do and try in each of their learning activities.
\end{abstract}

Keywords: modeling the way, learning motivation

\begin{abstract}
ABSTRAK
Penelitian ini dilakukan dalam dua siklus, yaitu siklus I yang dilaksanakan 2 kali pertemuan dan siklus II yang juga dilaksanakan sebanyak 2 kali pertemuan. Penelitian ini dilaksanakan selama 3 bulan dan ditambah dengan merangkum semua hasil penelitian yang ada. Hasilnya peningkatan belajar siswa Kelas V SDN 30 Parepare melalui model pembelajaran kooperatif Modelling The Way ini adalah (i) pada siklus I, termasuk kategori sedang dengan jumlah nilai rata-rata 66,25 sedangkan pada siklus II mengalami kemajuan dengan kategori sangat tinggi dengan
\end{abstract}


nilai rata-rata 78,13, (ii) terdapat peningkatan hasil belajar siswa Kelas V SDN 30 Parepare melalui model pembelajaran kooperatif Modelling the Way, baik secara kualitatif maupun kuantitatif. Maka model ini dinilai cukup efektif diterapkan dalam mengajar, khususnya bidang studi IPS di jenjang SD, karena dapat meningkatkan hasil belajar siswa, baik dalam mengerjakan tugas-tugasnya di sekolah maupun berusaha memberikan kesempatan kepada siswa untuk berbuat dan berusaha dalam setiap kegiatan belajarnya.

Kata kunci: $\quad$ modelling the way, motivasi belajar

\section{PENDAHULUAN}

\section{Latar Belakang}

Pendidikan merupakan usaha sadar dan terencana untuk mewujudkan suasana belajar dan proses pembelajaran agar peserta didik aktif mengembangkan potensi dirinya untuk memiliki kekuatan spiritual, keagamaan, pengendalian diri, kepribadian, kecerdasan, akhlak mulia serta keterampilan yang diperlukan dirinya, masyarakat, bangsa dan negara. Pendidikan merupakan tanggung jawab bersama, antara pemerintah, masyarakat dan orang tua. Kerjasama antara ketiga pihak tersebut diharapkan dapat menciptakan/mewujudkan tujuan pendidikan nasional.

Seiring dengan kemajuan zaman, pengetahuan pun juga semakin berkembang. Suatu negara bisa lebih maju jika negara tersebut memiliki sumber daya manusia yang mengetahui berbagai ilmu pengetahuan disamping teknologi yang sedang berkembang pesat sekarang ini. Mata pelajaran IPS di sekolah dasar merupakan perwujudan dari satu pendekatan interdisipliner dari pelajaran ilmu-ilmu sosial. IPS mengkaji seperangkat peristiwa, konsep dan generalisasi yang berkaitan dengan isu sosial. Melalui mata pelajaran IPS, peserta didik diarahkan untuk dapat menjadi warga Negara Indonesia yang demokratis, dan bertanggung jawab, serta warga dunia yang cinta damai. Mata pelajaran IPS dirancang untuk mengembangkan kemampuan anak didik agar menjadi anggota masyarakat yang memiliki pengetahuan, pemahaman, dan kemampuan analisis terhadap kondisi sosial masyarakat dalam memasuki kehidupan bermasyarakat yang dinamis, Dalam kurikulum Tingkat Satuan Pendidikan (KTSP) 2006 
tercantum bahwa salah satu tujuan pengajaran IPS di SD adalah memiliki komitmen dan kesadaran terhadap nilai-nilai sosial dan kemanusiaan.

Wachidi dalam Kunandar merumuskan bahwa tujuan pokok pengajaran pengetahuan sosial, yaitu:

1. Memberikan pengetahuan kepada manusia bagaimana bersikap terhadap benda-benda disekitarnya, 2. memberikan pengetahuan kepada manusia bagaimana cara berhubungan dengan manusia lainnya, 3. memberikan pengetahuan kepada manusia bagaimana cara berhubungan dengan Tuhannya. ${ }^{1}$

Surahman dan Mukminan mengemukakan bahwa:

Pada dasarnya tujuan dari pendidikan IPS secara umum adalah untuk mendidik dan memberi bekal kemampuan dasar kepada siswa untuk mengembangkan diri sesuai dengan bakat, minat, kemampuan dan lingkungannya, serta berbagai bekal bagi siswa untuk melanjutkan pendidikan ke jenjang lebih tinggi. ${ }^{2}$

Jadi dapat disimpulkan bahwa tujuan mata pelajaran IPS adalah mendidik dan memberikan pengetahuan kepada siswa tentang bagaimana cara berhubungan dengan manusia lain dalam hal ini memiliki kemampuan berkomunikasi, bakat, minat, kerjasama dan kompetisi dalam masyarakat dan lingkungannya.

Namun kenyataan yang ada di sekolah, jauh sekali dengan apa yang diharapkan. Saat belajar di sekolah, siswa jarang sekali diberi gambaran bahwa ilmu sosial adalah keilmuan yang sangat dekat dengan kehidupan mereka. Materi yang diberikan selalu menitik beratkan kepada hafalan tanpa bekal keterampilan yang diperlukan dalam menghadapi masalah di kehidupan sehari-harinya. Berbagai keterampilan dalam ilmu sosial sering dilupakan di sekolah padahal sangat penting untuk dimiliki oleh siswa.

Sering kita dengar para siswa khususnya siswa SD mengeluh jika dihadapkan pada mata pelajaran IPS. Keluhan-keluhan ini berakar pada proses pembelajaran yang tidak menanamkan wawasan, keterampilan, dan konsep yang nyata pada siswa yang menyebabkan ketuntasan belajar siswa belum tercapai dengan baik.

\footnotetext{
${ }^{1}$ Kunandar. Langkah Mudah Penelitian Tindakan Kelas Sebagai Pengembangan Profesi Guru. (Jakarta: Rajawali Pers., 2008), h. 262.

${ }^{2}$ Edy Surahman dan Mukminan, "Peran Guru IPS Sebagai Pendidik dan Pengajar dalam Meningkatkan Sikap Sosial dan Tanggung Jawab Sosial Siswa SMP”, Harmoni Sosial: Jurnal Pendidikan IPS, Volume 4, No 1, Maret 2017 (1-13), h. 5.
} 
Dari uraian ini dapat diasumsikan bahwa mata pelajaran pengetahuan sosial mempunyai nilai yang strategis dan penting dalam mempersiapkan sumber daya manusia yang unggul, handal, dan bermoral semenjak dini. Hal ini terungkap berdasarkan pra penelitian yang dilakukan penulis saat melakukan observasi pada tanggal 10 Agustus 2018 di SD Negeri 30 Parepare. Setelah diadakan observasi dengan melihat hasil ulangan IPS dari siswa kelas V SD Negeri 30 Parepare, hasilnya masih di bawah rata-rata dari pembelajaran yang dikatakan tuntas. Pembelajaran tuntas secara individual apabila siswa di kelas mendapatkan nilai 75 ke atas dan pembelajaran secara klasikal proses belajar mengajar dikatakan tuntas apabila $70 \%$ siswa di kelas memperoleh nilai 75 ke atas.

Melihat situasi ini, setelah peneliti mengobservasi lebih lanjut ternyata ada keganjalan yang terjadi sehingga hasil belajar siswa tidak sesuai yang diharapkan. Hal ini disebabkan oleh dua faktor yakni dari guru dan faktor dari siswa. Faktor yang bersumber dari guru di antaranya: (1) Pembelajaran masih bersifat monoton yaitu pembelajaran yang berpusat pada guru (Teacher Centered) sehingga situasi belajarnya terpusat pada pengajar, (2) Guru tidak menggunakan alat peraga atau media yang relevan dengan pembelajaran, dan (3) Strategi guru kurang mampu menghidupkan suasana belajar siswa secara optimal. Dalam proses belajar mengajar di kelas siswa tidak bersemangat dan siswa merasa bosan karena tidak dilibatkan dalam proses belajar mengajar.

Faktor yang bersumber dari siswa diantaranya: (1) Siswa menerima materi pelajaran secara pasif, dimana aktivitas siswa hanya Duduk, Dengar, Catat, dan Hafal, (2) Kurangnya interaksi dengan guru dan siswa lain dan (3) Siswa menganggap bahwa pelajaran IPS adalah pelajaran yang membosankan sehingga tidak antusias dalam mengikuti pelajaran dan memilih mengerjakan aktivitas lain seperti ribut, mengganggu siswa lainnya, berjalan ke depan kelas sehingga suasana kelas menjadi kurang kondusif untuk belajar.

Pada mata pelajaran IPS yang dinilai siswa sangat membosankan, peneliti menyadari bahwa butuh pembelajaran yang menyenangkan tetapi tidak meninggalkan kontek awal yaitu kebermaknaan yang nantinya akan mampu memberikan pemahaman yang utuh terhadap siswa kelas V sehingga dapat memahami materi pembelajaran IPS. Untuk menyelesaikan persoalan dan penyebab persoalan di atas maka peneliti menawarkan suatu model pembelajaran yang sifatnya kooperatif yaitu dengan penggunaan model pembelajaran Modelling The Way. 


\section{Permasalahan}

Berdasarkan pada latar belakang masalah yang telah dibahas pada subbab sebelumnya, maka rumusan masalah yang dapat dirumuskan pada penelitian ini adalah: "apakah dengan melalui penerapan pembelajaran Modelling The Way dapat meningkatkan hasil belajar Ilmu Pengetahuan Sosial siswa kelas V SD Negeri 30 Parepare?"

\section{METODE PENELITIAN}

\section{Jenis dan Lokasi Penelitian}

Jenis penelitian yang digunakan adalah penelitian tindakan kelas (class action research) pada siswa kelas V SD Negeri 30 Parepare. Penelitian yang dilakukan di kelas ini dengan penekanan pada penyempurnaan atau peningkatan hasil belajar dan proses belajar Ilmu Pengetahuan Sosial.

Selanjutnya Arikunto menyatakan bahwa penelitian tindakan kelas memiliki ciri-ciri sebagai berikut: “(1) bersifat kolaboratif; (2) berfokus pada problem/masalah praktis; (3) penekanan pada pengembangan profesional; dan (4) memerlukan adanya struktur proyek yang memungkinkan partisipasi untuk berkomunikasi". 3

Lokasi penelitian tindakan kelas ini adalah SD Negeri 30 Parepare. Alasan sekolah ini dijadikan sebagai tempat penelitian dikarenakan oleh: (1) hasil belajar Ilmu Pengetahuan Sosial siswa pada level kategori sedang; (2) SD Negeri 30 Parepare bersikap terbuka (open mind) dan bersedia menerima pembaharuan dalam proses pembelajaran; (3) kepala sekolah dan guru bidang studi serta wali kelas bersedia untuk berkolaborasi dalam penelitian sehingga menunjang proses penelitian; dan (4) juga sebagai usaha peneliti untuk melahirkan kembali (reborn) penelitian tindakan kelas dalam rangka memperbaiki proses pembelajaran Ilmu Pengetahuan Sosial.

\footnotetext{
${ }^{3}$ Suharsimi Arikunto, dkk, Penelitian Tindakan Kelas. (Jakarta: Bumi Aksara, 2008).
} 


\section{Subjek Penelitian}

\section{Siswa}

Dalam kegiatan pembelajaran ini, tentunya melibatkan peran serta siswa secara langsung dan aktif, yaitu seluruh kelas V SD Negeri 30 Parepare.

2. Guru

Kompetensi guru dalam memberikan pembelajaran yang aktif, kreatif, efektif dan menyenangkan dengan menggunakan pendekatan pembelajaran berbasis realistik dan psikopedagogis sehingga memberikan motivasi tersendiri terhadap minat siswa dalam belajar di kelas maupun diluar kelas.

\section{Populasi dan Sampel}

\section{Populasi}

Populasi yang digunakan dalam penelitian tindakan kelas ini adalah seluruh siswa kelas V SD Negeri 30 Parepare yang menempuh pendidikannya pada tahun pelajaran 2018/2019.

2. Sampel

Sampel yang digunakan dalam penelitian adalah dengan menggunakan metode total sampling (sampel yang diambil secara keseluruhan). Dan sampel yang terpilih adalah kelas $\mathrm{V}$ dengan jumlah sampel 32 orang siswa yang terdaftar pada semester I tahun pelajaran $2018 / 2019$.

\section{Langkah-langkah Pembuatan Perangkat Pembelajaran Inovatif seperti RPP dan Instrumen Evaluasi}

Suatu pembelajaran Ilmu Pengetahuan Sosial di SD/MI pada prinsipnya adalah serangkaian proses yang dilakukan bersama-sama antara guru dengan siswa untuk memahami pembelajaran Ilmu Pengetahuan Sosial secara aktif berdasarkan pengalaman dan pengetahuan sebelumnya. Belajar Ilmu Pengetahuan Sosial bukan semata-mata pandai dan mahir menganalisa aspek-aspeknya, akan tetapi membutuhkan kecakapan berpikir dan berargumentasi untuk menyelesaikan soal-soal atau permasalahanpermasalahan dalam pembelajaran Ilmu Pengetahuan Sosial. 
Persiapan pembelajaran yang harus dirancang oleh guru secara garis besar meliputi persiapan:

1. Sumber belajar: buku Ilmu Pengetahuan Sosial Kelas V SD/MI terbitan Pusat Kurikulum dan Perbukuan Kementerian Pendidikan Nasional dan buku penunjang lainnya.

2. Lembar kerja siswa.

3. Media pembelajaran.

4. Kegiatan assesmen: penilaian dan proses.

5. RPP pembelajaran Ilmu Pengetahuan Sosial.

Langkah-langkah minimal dari penyusunan rencana pelaksanaan pembelajaran (RPP), dimulai dari mencantumkan identitas RPP, tujuan pembelajaran, materi pembelajaran, langkah-langkah kegiatan pembelajaran, sumber belajar dan penilaian. Setiap komponen mempunyai arah pengembangan masing-masing, namun masih merupakan satu kesatuan.

1. Mencantumkan identitas pembelajaran

Terdiri atas nama sekolah, mata pelajaran, kelas, standar kompetensi, kompetensi dasar, indikator dan alokasi waktu. Hal-hal yang perlu diperhatikan adalah sebagai berikut:

a. RPP boleh disusun untuk satu kompetensi dasar.

b. Standar kompetensi, kompetensi dasar dan indikator dikutip dari silabus karena standar kompetensi, kompetensi dasar dan indikator adalah salah satu alur pikir yang saling terkait dan tidak dapat dipisahkan.

c. Indikator merupakan:

1) Ciri pelaku (bukti terukur) yang dapat memberikan gambaran bahwa peserta didik telah mencapai kompetensi dasar.

2) Penanda pencapaian kompetensi dasar yang ditandai oleh perubahan perilaku yang dapat diukur mencakup sikap, pengetahuan dan keterampilan.

3) Dikembangkan sesuai dengan karakteristik peserta didik, satuan pendidikan dan potensi daerah.

4) Rumusannya menggunakan kata kerja operasional yang diukur dan atau dapat diobservasi.

5) Digunakan sebagai dasar untuk menyusun alat penilaian.

d. Alokasi waktu diperhitungkan untuk pencapaian satu kompetensi dasar dan dinyatakan dalam jam. Suatu kompetensi dasar dapat 
diperhitungkan dalam satu atau beberapa kali pertemuan tergantung pada kompetensi dasarnya.

2. Merumuskan tujuan pembelajaran

Tujuan pembelajaran merupakan output (hasil langsung) dari suatu paket kegiatan pembelajaran.

3. Menentukan materi pembelajaran

Untuk memudahkan penetapan materi pembelajaran, dapat diacu dari indikator.

4. Menentukan metode pembelajaran

Metode dapat diartikan sebagai metode, tetapi dapat juga diartikan sebagai model atau pendekatan pembelajaran, bergantung pada karakteristik dan atau strategi yang dipilih. Karena itu pada bagian ini dicantumkan pendekatan pembelajaran peserta didik:

a. Pendekatan pembelajaran yang digunakan, misalnya pendekatan proses, kontekstual langsung, pemecahan masalah dan sebagainya.

b. Metode-metode yang digunakan misalnya ceramah, inkuiri, observasi, tanya jawab dan sebagainya.

5. Menetapkan kegiatan pembelajaran

a. Untuk mencapai suatu kompetensi dasar harus dicantumkan langkah-langkah kegiatan setiap kali pertemuan. Pada dasarnya, langkah-langkah kegiatan memuat unsur-unsur kegiatan pendahuluan/pembuka, kegiatan inti dan kegiatan akhir/penutup.

b. Langkah-langkah pembelajaran dimungkinkan disusun dalam bentuk seluruh rangkaian kegiatan, sesuai dengan karakteristik model pembelajaran yang dipilih, menggunakan ukuran sintaks atau modelnya. Oleh karena itu, kegiatan pendahuluan/pembuka, kegiatan inti dan kegiatan akhir/penutup tidak harus ada dalam setiap pertemuan.

6. Memilih sumber belajar

Pemilihan sumber belajar mengacu pada perumusan yang ada dalam silabus pembelajaran yang dikembangkan. Sumber belajar mencakup sumber rujukan, lingkungan, media, narasumber, alat dan bahan. Sumber belajar dituliskan secara lebih operasional, dan bisa langsung dinyatakan bahan ajar apa yang digunakan. Misalnya, sumber belajar dalam silabus dituliskan buku referensi, maka dalam RPP harus dicantumkan bahan ajar yang sebenarnya. Jika menggunakan buku, maka harus ditulis judul buku teks tersebut, 
pengarang dan halaman yang diacu. Jika bahan ajar berbasis data dan teknologi informasi berbasis internet, maka harus ditulis nama file, folder penyimpanan dan bagian atau link URL (Uniform Research Location) dan atau alamat website yang digunakan sebagai acuan pembelajaran.

7. Menentukan penilaian

Penilaian dijabarkan atas teknik penilaian, bentuk instrumen dan instrumen yang dipakai. Adapun langkah-langkah penyusunan alat evaluasi (assessment) dapat dilakukan dengan:
a. Menentukan tujuan
b. Menentukan instrumen
c. Melaksanakan instrumen
d. Menganalisis instrument
e. Merefleksi instrumen
f. Melaporkan hasil penelitian

\section{Analisis Data}

Analisis data yang dilakukan dengan cara mengelompokkan data aspek guru dan aspek siswa. Teknik yang digunakan adalah teknik analisis data kualitatif yang dikembangkan oleh Miles dan Huberman, (Kunandar, 2008:101) yang terdiri dari tiga tahap kegiatan yaitu: 1) Menyelidiki data, 2) Menyajikan data, 3) Menarik kesimpulan dan verifikasi data.

\section{Indikator Keberhasilan}

Indikator keberhasilan dalam penelitian tindakan ini meliputi indikator proses dan hasil dalam penggunaan pendekatan metode Modelling The Way dalam meningkatkan pemahaman fungsi pembelajaran IPS. Hipotesis tindakan dalam penelitian ini adalah penerapan pendekatan metode Modelling The Way menjadi salah satu alternatif solusi yang tepat untuk meningkatkan pemahaman terhadap fungsi pembelajaran IPS di kelas V SD Negeri 30 Parepare. Adapun kriteria yang digunakan untuk mengungkapkan tingkat penguasaan siswa dalam memahami materi adalah sesuai dengan kriteria standar yang diungkapkan Nurkancana (1986:39) sebagai berikut:

Tingkat penguasaan $90 \%$ - 100\% dikategorikan sangat tinggi, $80 \%$ $89 \%$ dikategorikan tinggi, $65 \%$ - 79\% dikategorikan sedang, $55 \%$ - 
64\% dikategorikan rendah dan 0\% - 54\% dikategorikan sangat rendah.

Berdasarkan kriteria standar tersebut, maka peneliti menentukan indikator keberhasilan penelitian tindakan kelas ini tercapai apabila di kelas V SD Negeri 30 Parepare pada pokok bahasan fungsi pembelajaran IPS dengan pendekatan metode Modelling The Way mempunyai nilai setiap siswa rata-rata minimal $\geq 7$ dan ketuntasan belajar kelas $\geq 70 \%$.

\section{HASIL PENELITIAN}

\section{Analisis data kuantitatif}

1. Hasil tes siklus I

Tes hasil belajar Ilmu Pengetahuan Sosial pada siklus I setelah proses pembelajaran datanya adalah sebagai berikut:

Tabel 4.1

Statistik Skor Hasil Belajar Ilmu Pengetahuan Sosial Siklus I Siswa Kelas V SD Negeri 30 Parepare

\begin{tabular}{|c|c|}
\hline Statistik & Skor \\
\hline Subjek penelitian & 32 \\
\hline Skor maksimum ideal & 100 \\
\hline Skor rata-rata & 66,25 \\
\hline Skor terendah & 45,00 \\
\hline Skor tertinggi & 100,00 \\
\hline
\end{tabular}

Berdasarkan tabel 4.1 diperoleh hasil bahwa skor rata-rata hasil belajar Ilmu Pengetahuan Sosial kelas V SD Negeri 30 Parepare setelah pemberian tindakan siklus I adalah 66,25 dari skor ideal yang mungkin dicapai yaitu 100,00. Skor tertinggi yakni 100 dan terendah 45,00. Jika skor hasil belajar Ilmu Pengetahuan Sosial siswa tersebut dikelompokkan ke dalam lima kategori, maka diperoleh distribusi frekuensi dan persentase seperti disajikan pada tabel 4.2 berikut ini. 
Tabel 4.2

\section{Statistik Frekuensi dan Persentase Skor Hasil Belajar Ilmu Pengetahuan Sosial Siklus I}

\begin{tabular}{|c|c|c|c|c|}
\hline Nomor & Interval & Kriteria & Frekuensi & $\%$ \\
\hline 1 & $89-100$ & Sangat tinggi & 2 & 6,25 \\
\hline 2 & $78-88$ & Tinggi & 4 & 12,5 \\
\hline 3 & $67-77$ & Sedang & 7 & 21,87 \\
\hline 4 & $56-66$ & Rendah & 10 & 31,25 \\
\hline 5 & $\leq 55$ & Sangat rendah & 9 & 28,13 \\
\hline \multicolumn{3}{|c|}{ Jumlah } & 32 & 100,00 \\
\hline
\end{tabular}

Berdasarkan tabel 4.2 diperoleh bahwa 32 orang siswa yang mengikuti tes siklus I pada kelas V SD Negeri 30 Parepare, terdapat 28,13 $\%$ yang hasil belajarnya masuk dalam kategori sangat rendah, 31,25\% masuk ke dalam kategori rendah dan 21,87 \% masuk dalam kategori sedang. Kemudian 12,5 \% masuk dalam kategori tinggi dan $2 \%$ masuk dalam kategori sangat tinggi.

Berdasarkan tabel 4.1 dan tabel 4.2, maka diperoleh skor rata-rata hasil belajar siswa pada siklus I yaitu 66,25. Jika skor rata-rata siswa disinkronisasikan dengan tabel 4.2, maka skor rata-rata hasil belajar Ilmu Pengetahuan Sosial pada siklus I masuk dalam kategori sedang.

2. Hasil tes siklus II

Pada siklus II ini dilaksanakan tes hasil belajar Ilmu Pengetahuan Sosial dengan bentuk tes essai. Tes hasil belajar tersebut dilaksanakan setelah penyajian beberapa pokok bahasan materi. Adapun data skor hasil belajar siklus II dapat dlihat pada tabel dibawah ini:

Tabel 4.3

Statistik Skor Hasil Belajar Ilmu Pengetahuan Sosial Siklus II Siswa Kelas V SD Negeri 30 Parepare

\begin{tabular}{|c|c|}
\hline Statistik & Skor \\
\hline Subjek penelitian & 32 \\
\hline Skor maksimum ideal & 100,00 \\
\hline Skor rata-rata & 78,13 \\
\hline Skor terendah & 45,00 \\
\hline Skor tertinggi & 100,00 \\
\hline
\end{tabular}


Berdasarkan tabel 4.3 diperoleh data bahwa rata-rata hasil belajar Ilmu Pengetahuan Sosial siswa kelas V SD Negeri 30 Parepare setelah pemberian tindakan pada siklus II adalah 78,13 dari skor nilai ideal yang bisa dicapai yaitu 100. Nilai tertinggi yang dicapai yakni 100,00 dan nilai terendah 45,00. Jika hasil belajar Ilmu Pengetahuan Sosial siswa tersebut dikelompokkan ke dalam lima kategori, maka diperoleh distribusi frekuensi dan persentase seperti yang dijabarkan pada tabel 4.4 berikut ini:

Tabel 4.4

Statistik Frekuensi dan Persentase Skor Hasil Belajar Ilmu Pengetahuan Sosial Siklus II

\begin{tabular}{|c|c|c|c|c|}
\hline Nomor & Interval & Kriteria & Frekuensi & $\%$ \\
\hline 1 & $89-100$ & Sangat tinggi & 9 & 28,13 \\
\hline 2 & $78-88$ & Tinggi & 6 & 18,75 \\
\hline 3 & $67-77$ & Sedang & 9 & 28,13 \\
\hline 4 & $56-66$ & Rendah & 5 & 15,62 \\
\hline 5 & $\leq 55$ & Sangat rendah & 3 & 9,37 \\
\hline \multicolumn{3}{|c|}{ Jumlah } & 32 & 100,00 \\
\hline
\end{tabular}

Berdasarkan pada tabel 4.4, diperoleh deskripsi data bahwa dari 32 orang siswa kelas V SD Negeri 30 Parepare yang mengikuti tes, terdapat 9,37\% yang hasil belajarnya masuk dalam kategori sangat rendah, 15,62\% masuk dalam kategori rendah dan 28,13 masuk dalam kategori sedang. Kemudian ada 18,75 \% masuk dalam kategori tinggi dan pada akhirnya $28,13 \%$ masuk dalam kategori sangat tinggi.

Berdasarkan tabel 4.3 dan tabel 4.4, maka diperoleh rata-rata hasil belajar siswa pada siklus II yaitu 78,13. Jika rata-rata nilai siswa tersebut dikonsultasikan dengan tabel 4.4, maka nilai rata-rata hasil belajar pada siklus II masuk dalam kategori tinggi.

\section{Analisis data kualitatif}

1. Siklus I

Data aktivitas siswa pada siklus I diperoleh melalui hasil pengamatan aktivitas dan sikap siswa selama proses pembelajaran di setiap kali pertemuan. Adapun deskripsi aktivitas siswa pada siklus I dapat dilihat pada tabel berikut ini. 
Tabel 4.5

\section{Distribusi Frekuensi Aktivitas dan Sikap Siswa pada Siklus I}

\begin{tabular}{|c|c|c|c|c|c|}
\hline \multirow{2}{*}{ Kriteria Penilaian } & \multicolumn{4}{|c|}{ Pertemuan } & \multirow{2}{*}{$\begin{array}{l}\text { Persentase } \\
(\%)\end{array}$} \\
\hline & I & II & III & IV & \\
\hline Kehadiran & 32 & 32 & 32 & \multirow{6}{*}{$\begin{array}{c}\text { Tes } \\
\text { siklus } \\
\quad \text { I }\end{array}$} & 100,00 \\
\hline $\begin{array}{l}\text { Siswa yang memperhatikan } \\
\text { pembahasan materi pembelajaran }\end{array}$ & 18 & 7 & 32 & & 59,37 \\
\hline $\begin{array}{l}\text { Siswa yang bertanya tentang } \\
\text { materi yang belum dimengerti }\end{array}$ & 5 & 7 & 8 & & 20,83 \\
\hline $\begin{array}{l}\text { Siswa yang menjawab pertanyaan } \\
\text { guru }\end{array}$ & 12 & 17 & 9 & & 39,58 \\
\hline $\begin{array}{l}\text { Siswa menanggapi jawaban } \\
\text { temannya }\end{array}$ & 8 & 15 & 12 & & 36,45 \\
\hline $\begin{array}{l}\text { Siswa menyimpulkan materi } \\
\text { pelajaran }\end{array}$ & 18 & 19 & 32 & & 71,91 \\
\hline
\end{tabular}

Berdasarkan tabel 4.5 diatas diperoleh data bahwa dari 32 siswa kelas V SD Negeri 30 Parepare, kehadiran siswa rata-rata mencapai $100 \%$. Siswa yang memperhatikan pembahasan materi pembelajaran rata-rata $49,37 \%$, siswa yang bertanya tentang materi yang belum dimengerti ratarata $20,83 \%$. Kemudian siswa yang menjawab pertanyaan guru mencapai $39,58 \%$. Siswa yang melakukan kegiatan lain pada saat proses belajar mengajar berlangsung mencapai $36,45 \%$ dan siswa yang menyimpulkan materi pelajaran sebanyak $71,91 \%$.

2. Siklus II

Data aktivitas siswa pada siklus II diperoleh melalui hasil pengamatan aktivitas dan sikap siswa selama proses pembelajaran di setiap pertemuan. Adapun deskripsi aktivitas siswa pada siklus II dapat dilihat pada tabel berikut ini. 
Tabel 4.6

\section{Distribusi Frekuensi Aktivitas dan Sikap Siswa pada Siklus II}

\begin{tabular}{|c|c|c|c|c|c|}
\hline \multirow{2}{*}{ Kriteria Penilaian } & \multicolumn{4}{|c|}{ Pertemuan } & \multirow{2}{*}{$\begin{array}{l}\text { Persentase } \\
(\%)\end{array}$} \\
\hline & I & II & III & IV & \\
\hline Kehadiran & 32 & 32 & 32 & \multirow{6}{*}{$\begin{array}{c}\text { Tes } \\
\text { siklus } \\
\quad \text { II }\end{array}$} & 100,00 \\
\hline $\begin{array}{l}\text { Siswa yang memperhatikan } \\
\text { pembahasan materi pembelajaran }\end{array}$ & 14 & 15 & 18 & & 48,96 \\
\hline $\begin{array}{l}\text { Siswa yang bertanya tentang } \\
\text { materi yang belum dimengerti }\end{array}$ & 5 & 7 & 11 & & 23,95 \\
\hline $\begin{array}{l}\text { Siswa yang menjawab pertanyaan } \\
\text { guru }\end{array}$ & 12 & 16 & 10 & & 39,58 \\
\hline $\begin{array}{l}\text { Siswa menanggapi jawaban } \\
\text { temannya }\end{array}$ & 10 & 14 & 16 & & 41,67 \\
\hline $\begin{array}{l}\text { Siswa menyimpulkan materi } \\
\text { pelajaran }\end{array}$ & 18 & 19 & 32 & & 71,87 \\
\hline
\end{tabular}

Berdasarkan tabel 4.6 diatas diperoleh informasi bahwa dari 32 siswa kelas V SD Negeri 30 Parepare, kehadiran siswa rata-rata mencapai $100 \%$. Siswa yang memperhatikan pembahasan materi pembelajaran ratarata $48,96 \%$, siswa yang bertanya tentang materi yang belum dimengerti rata-rata mencapai $23,95 \%$. Kemudian siswa yang menjawab pertanyaan guru mencapai 39,58 \%. Siswa yang menanggapi jawaban temannya mencapai $41,67 \%$ dan siswa yang menyimpulkan materi pelajaran mencapai angka $71,87 \%$.

\section{PEMBAHASAN}

Peningkatan hasil belajar Ilmu Pengetahuan Sosial siswa kelas V SD Negeri 30 Parepare setelah melaksanakan pembelajaran dengan metode Modelling The Way pada siklus I dan siklus II dapat dilihat pada tabel dibawah ini.

Dengan memperhatikan tabel diatas, dapat dilihat bahwa adanya hasil yang menampakkan peningkatan hasil belajar siswa setelah dua kali dilaksanakan tes siklus. Pada siklus I terdapat 9 siswa yang berada dalam kategori sangat rendah $(28,13)$, dan pada siklus II tersisa 3 orang $(9,37 \%)$ 
terdapat dalam kategori ini. Selanjutnya pada siklus I terdapat 10 orang siswa atau 31,25\% berada dalam kategori rendah dan pada siklus II terdapat 5 siswa (15,62 \%) yang berada dalam kategori ini. Selanjutnya pada kategori sedang untuk siklus I terdapat 7 orang siswa atau $21,87 \%$ berada dalam kategori ini, dan pada siklus II terdapat 9 siswa $(28,13 \%)$ berada dalam kategori ini. Kemudian pada kategori tinggi untuk siklus I terdapat 4 orang siswa atau 12,5\% berada pada kategori ini, dan untuk siklus II terdapat 6 orang siswa atau 18,75\% berada pada kategori ini. Selanjutnya pada kategori sangat tinggi untuk siklus I terdapat 2 orang siswa atau 6,25 $\%$ berada pada kategori ini, dan untuk siklus II meningkat menjadi 9 orang siswa atau $28,13 \%$ berada dalam kategori ini.

Dalam analisis deskriptif menunjukkan bahwa tingkat penguasaan materi siswa kelas V SD Negeri 30 Parepare pada siklus I hanya terdapat 2 orang siswa $(6,25 \%)$ yang berada pada tingkat penguasaan sangat tinggi, maka pada siklus II mengalami peningkatan yakni 9 orang siswa $(28,13 \%)$ berada pada kategori ini. Selanjutnya pada siklus I terdapat 9 orang siswa atau $28,13 \%$ yang berada pada tingkat penguasaan sangat rendah dan pada siklus II menurun menjadi 3 orang siswa $(9,37 \%)$ berada pada kategori sangat rendah.

Selanjutnya berdasarkan hasil pengamatan sikap siswa di kelas selama kegiatan belajar melalui model pembelajaran Modelling The Way ternyata mampu untuk mengubah sikap siswa dan dapat meningkatkan kreativitas dan aktivitas belajar siswa serta menumbuhkan rasa saling kerjasama antar siswa. Terlihat pada pelaksanaan siklus I siswa sudah mulai antusias dan termotivasi mengikuti kegiatan pembelajaran dengan mengkonstruksi dan menemukan sesuatu yang baru melalui model atau contoh. Walaupun dari kegiatan tersebut masih terdapat sebagian siswa yang kurang ikut berpartisipasi aktif dalam kegiatan pembelajaran.

Pada siklus II siswa lebih antusias dalam mengikuti pembelajaran yang ditandai dengan jumlah siswa yang berani mengajukan pertanyaan, menjawab pertanyaan dan menyampaikan pendapatnya. Selain itu, sebagian besar siswa sudah mampu memahami pelajaran yang telah mereka pelajari dan merefleksikan penerapannya pada kegiatan yang nyata. 


\section{KESIMPULAN}

Adapun kesimpulan yang dapat diambil setelah pelaksanaan penelitian tindakan kelas dengan menerapkan model pembelajaran tipe Modelling The Way selama dua siklus sebagai berikut:

1. Rata-rata hasil belajar Ilmu Pengetahuan Sosial, dalam hal ini materi Ilmu Pengetahuan Sosial yang diajarkan pada siswa kelas V di SD Negeri 30 Parepare adalah sebesar 66,25\% dan tergolong dalam kategori sedang. Dan pada siklus II hasil belajar siswa meningkat secara signifikan dengan nilai rata-rata adalah sebesar 78,13\% dan tergolong dalam kategori tinggi.

2. Model pembelajaran Modelling The Way cocok diajarkan di SD Negeri 30 Parepare, khususnya pada materi Ilmu Pengetahuan Sosial, hal ini dibuktikan dengan nilai rata-rata hasil belajar yang mengalami peningkatan secara signifikan setelah proses pembelajaran menggunakan model Modelling The Way.

3. Model pembelajaran Modelling The Way dapat dijadikan sebagai salah satu model pembelajaran yang cocok diajarkan bagi semua jenis mata pelajaran, khususnya di tingkat sekolah dasar.

4. Dalam melaksanakan proses belajar Ilmu Pengetahuan Sosial, model Modelling The Way dapat digunakan sebagai salah satu pendekatan pembelajaran untuk meningkatkan hasil belajar siswa, khususnya dalam pelajaran Ilmu Pengetahuan Sosial di SD Negeri 30 Parepare.

\section{DAFTAR PUSTAKA}

Ali, Muhammad Daud, 1997, Ilmu Pengetahuan Sosial, Jakarta: Raja Grafindo Persada.

Alwi, Hasan, 2001, Kamus Ilmu Pengetahuan Sosial Jilid 3, Jakarta: Balai Pustaka.

Amirul, Hadi dan Haryono, 2005, Metodologi Penelitian Pendidikan, Bandung: Pustaka Setia.

Arikunto, Suharsimi, dkk, 2008, Penelitian Tindakan Kelas, Jakarta: Bumi Aksara. 
Azra, Azyumardi, 2002, Paradigma Baru Pendidikan Ilmu Pengetahuan Sosial, Cet.1, Jakarta: Kompas.

Azwar, Lalu Muhammad, 1993, PBM Pola CBSA, Surabaya: Usaha Nasional.

Azwar, Saifudin, 2001, Metodologi Penelitian, Yogyakarta: Pustaka Pelajar.

Bahri, Djamaroh, Syaiful, 2000, Guru dan Anak Didik dalam Interaksi Edukatif, Jakarta: Rineka Cipta.

Danim, Sudarwan, 2003, Agenda Pembaharuan Sistem Pendidikan, cet. 1, Yogyakarta: Pustaka Pelajar.

Setia.

, 2002, Menjadi peneliti Kualitatif, Bandung: Pustaka

Darwis, Djamaluddin, 1998, Strategi Belajar Mengajar, dalam Chabib Thoha (eds). PBM-PAI di Sekolah, Pustaka Pelajar.

Depag RI, 2004, Pedoman Ilmu Pengetahuan Sosial untuk Sekolah Umum (Tingkat Menengah), Jakarta.

Dimyati dan Mudjiono, 2002, Belajar dan Pembelajaran, Jakarta: Rineka Cipta.

Gulo, W, 2002, Strategi Belajar mengajar, Jakarta: Gramedia.

Hamalik, Oemar, 2001, Kurikulum dan Pembelajaran, Jakarta: Bumi Aksara.

Hildbrand, Verna, 1971 Curiculum of The Nursery School and Kindergarten, New York: Macmillan Publishing.

http://id.wikipedia.org/wiki/Belajar/ Artikel online; terakhir diakses pada 20 September 2018.

http://www.lpmpjabar.go.id/?q=node/883.html Artikel online; terakhir diakses pada 25 September 2018.

http://materikuliahku1.blogspot.com/2018/01/materi-mata-kuliah-ilmupengetahuan-sosial-.html. Artikel online; terakhir diakses pada 30 September 2018 
http://pakaguspy.wordpress.com/2018/05/08/strategi-pembelajaran-ilmu pengetahuan sosial-indonesia-di-sd/. Artikel online; terakhir diakses pada 2 Oktober 2018

http://mebermutu.org/media.php?module=detailreferensi\&id=69/. Artikel online; terakhir diakses pada 3 Oktober 2018.

Ismail (eds.) 2001, Paradigma Pendidikan Ilmu Pengetahuan Sosial, Yogyakarta: Pustaka Pelajar.

J. Krisnamurti, 1981, Education and The Significance of Life, New York: First Harper and New Paperback.

J.J. Hasibuan, 2000, Proses Belajar Mengajar, Bandung: Remaja Rosdakarya.

Jalaludin, 2001, Teologi Pendidikan, Jakarta: Raja Grafindo Persada.

Kolb D.A. dkk. "Learning by Doing”, http: // www. Engines 4.

Kunandar, 2008, Langkah Mudah Penelitian Tindakan Kelas Sebagai Pengembangan Profesi Guru, Jakarta: Rajawali Pers.

Madjid, Abdul dan Dian Andrayani, 2004, Ilmu Pengetahuan Sosial Berbasis Kompetensi (Konsep dan Implementasi Kurikulum 2004), Bandung: Remaja Rosdakarya.

Muhaimin, et. al., 2001, Paradigma Pendidikan Ilmu Pengetahuan Sosial, Bandung: Remaja Rosdakarya.

Surahman, Edy dan Mukminan, "Peran Guru IPS Sebagai Pendidik dan Pengajar dalam Meningkatkan Sikap Sosial dan Tanggung Jawab Sosial Siswa SMP", Harmoni Sosial: Jurnal Pendidikan IPS, Volume 4, No. 1, Maret 2017 (1-13). 